\title{
Extrapituitary GH in the chicken: underestimation of immunohistochemical staining by Carnoy's fixation
}

\author{
A E Murphy, H Peek, M-L Baudet and S Harvey \\ Department of Physiology, University of Alberta, Edmonton, Alberta T6G 2H7, Canada \\ (Requests for offprints should be addressed to S Harvey; Email: steve.harvey@ualberta.ca)
}

\begin{abstract}
GH has previously been shown to be present in peripheral extrapituitary tissues of chick embryos, but the cellular distribution of $\mathrm{GH}$ immunoreactivity is still uncertain because of differing immunohistochemical findings. The possibility that this uncertainty reflects differences in fixation of the embryonic tissues was assessed by comparing GH immunoreactivity in tissues fixed in $4 \%(\mathrm{w} / \mathrm{v})$ paraformaldehyde or Carnoy's fluid $(60 \%$ ethanol $(\mathrm{v} / \mathrm{v})$; $30 \%$ chloroform (v/v); $10 \%$ acetic acid (v/v)).

A widespread distribution of $\mathrm{GH}$ immunoreactivity was seen in paraformaldehyde-fixed tissues, although it was particularly intense in the spinal cord, dorsal and ventral root ganglia, notochord, myotome, epidermis, crop, heart, lung and humerus. In marked contrast, GH immunoreactivity in embryonic tissues fixed with Carnoy's was more discrete and mainly restricted to marginal and mantle layers of the spinal cord, spinal nerves, the ventral root
\end{abstract}

ganglia and the extensor nerve of the anterior limb bud. Since these are neural derivatives, Carnoy's fixation appears to preferentially result in neural GH staining, whereas GH staining in neural and non-neural tissues is seen after paraformaldehyde fixation. Carnoy's, because it is a precipitive fixative, may only fix large GH moieties, whereas GH in peripheral tissues includes numerous molecular variants, many of which are of relatively small size. Paraformaldehyde, because it is a cross-linking fixative, preferentially fixes peptides and small proteins, and it may therefore fix more GH moieties than Carnoy's fluid. Carnoy's fixation appears to underestimate $\mathrm{GH}$ immunoreactivity in immunohistochemical studies on the cellular distribution of $\mathrm{GH}$-like proteins in embryonic chicks.

Journal of Endocrinology (2003) 177, 223-234

\section{Introduction}

Growth hormone $(\mathrm{GH})$ gene expression primarily occurs in pituitary somatotrophs, although numerous extrapituitary sites of GH expression have been documented. Indeed, in domestic fowl, GH mRNA has been identified in the brain (Render et al. 1995a), in the thymus, bursa and spleen (Render et al. 1995b), in the testes and vas deferens (Harvey et al. 2002, A E Murphy, M Luna, C Arámburo, K L Hull \& S Harvey, unpublished observations), in the ovary (Luna et al. 2000), in the heart (Takeuchi et al. 2001) and in the eye (Takeuchi et al. 2001). In mammalian species, GH gene expression has additionally been determined in the placenta (Schwarzler et al. 1997), mammary gland (Mol et al. 1995a,b), liver (Recher et al. 2001), lung (Allen et al. 2000), salivary gland (Tresguerres et al. 1999), skin (Palmetshofer et al. 1995, Slominski et al. 2000) and in smooth muscle and endothelial cells of blood vessels (Wu et al. 1996, Recher et al. 2001). Proteins with GH immunoreactivity are also present in these sites and in other peripheral tissues (e.g. in teeth, kidney and gut; Kyle et al. 1981, Costa et al. 1993,
Zhang et al. 1997). Nevertheless, with the exception of limited studies on the nervous (Lechan et al. 1981, Ramesh et al. 2000, Takeuchi et al. 2001) and immune (Kao et al. 1992, Maggiano et al. 1994) systems, this immunoreactivity has been determined by radioimmunoassay of tissue extracts and its cellular location is largely unknown. Two immunohistochemical studies on the localization of $\mathrm{GH}$ in peripheral tissues of embryonic chicks have, however, been published (Harvey et al. 2000, Murphy \& Harvey 2001).

In one study, GH immunoreactivity was found to be abundant and widespread in the bodies of embryonic tissues (Harvey et al. 2000). This immunoreactivity was thought to be specific, since it was detectable by three different $\mathrm{GH}$ antibodies (two polyclonals, one monoclonal) and was completely lost following pretreatment of the primary antibodies with excess recombinant GH. A different tissue distribution of $\mathrm{GH}$ immunoreactivity was, however, observed in a more recent study (Murphy \& Harvey 2001), in which the cellular distribution of GH was restricted to discrete cells or tissue layers. The main difference between these two studies was the fixative used 
for immunohistochemistry: 4\% paraformaldehyde (Harvey et al. 2000) and Carnoy's fixative (Murphy \& Harvey 2001). Since different fixatives can result in quantitative and qualitative changes in protein detection (Chiu et al. 1994, Vince et al. 1997, Hemmer et al. 1998, Giaccone et al. 2000), the influence of fixation on the immunocytochemical detection of $\mathrm{GH}$ in chick embryos was therefore empirically assessed.

\section{Materials and Methods}

\section{Tissues}

Fertile White Leghorn chicken eggs from the University of Alberta Poultry Unit were incubated at $37^{\circ} \mathrm{C}$ in humidified air. The eggs were turned one quarter of a revolution each day during the incubation period. Whole embryos at embryonic day 7 (ED 7) of the 21-day period of embryogenesis were dissected and decapitated in phosphate-buffered saline (PBS; pH 7.4) prior to fixation. ED 7 embryos were used since pituitary somatotrophs do not differentiate until ED 12 to ED 14 (Porter 1997) and hence tissue $\mathrm{GH}$ immunoreactivity could not be due to the sequestration of pituitary GH. Peripheral tissues were similarly used to ensure that $\mathrm{GH}$ immunoreactivity was not due to pituitary GH detection.

\section{Fixation}

Tissues were collected into freshly prepared paraformaldehyde (4\% (w/v), in PBS; Sigma, Mississauga, Ontario, Canada) or Carnoy's fluid $(60 \%$ ethanol (v/v); $30 \%$ chloroform $(\mathrm{v} / \mathrm{v}) ; 10 \%$ acetic acid $(\mathrm{v} / \mathrm{v}))$. Paraformaldehyde is a cross-linking fixative that forms links (hydroxylmethylene bridges) between reactive end-groups of adjacent protein chains, whereas Carnoy's is a precipitant fixative that denatures proteins by destroying the hydrophobic bonds that hold together the tertiary structures of large protein molecules.

\section{Immunocytochemistry}

The headless embryos were fixed, overnight, at $4{ }^{\circ} \mathrm{C}$. They were then dehydrated in a graded series of alcohol (50\% $15 \mathrm{~min} ; \quad 70 \% \quad 15 \mathrm{~min} ; \quad 95 \% \quad 30 \mathrm{~min} ; \quad 100 \%$ $2 \times 30 \mathrm{~min}$ ) and cleared with Hemo-de (Fisher Scientific, Edmonton, Alberta, Canada) for $2 \times 30 \mathrm{~min}$. The tissues were then infiltrated with paraffin wax for $24 \mathrm{~h}$ at $60{ }^{\circ} \mathrm{C}$ under normal atmospheric pressure. Serial transverse $(8 \mu \mathrm{m})$ sections were then taken using a microtome and mounted onto charged slides (Fisher Scientific). Immunocytochemical staining was performed with commercial reagents (Vector Laboratories, Burlingame, CA, USA; Sigma) using the avidin-biotin-peroxidase (ABC) method
(Hsu et al. 1981). Sections were incubated overnight at $4{ }^{\circ} \mathrm{C}$ with a specific polyclonal antiserum raised in rabbits against native (pituitary) chicken GH (Harvey et al. 2000), diluted 1:1000 in 1\% normal goat serum. After incubation, the slides were washed three times for $5 \mathrm{~min}$ in PBS. Sections were then incubated for $1 \mathrm{~h}$ at room temperature in biotinylated goat anti-rabbit immunoglobin G (Sigma; 1:500). The slides were then washed in PBS and incubated in $\mathrm{ABC}$ reagent for $1 \mathrm{~h}$ at room temperature and washed in PBS. Staining was visualized using the chromogenic substrate, diaminobenzidine tetrahydrochloride (DAB) (Sigma), which resulted in a brown coloration. The specificity of staining was determined by preabsorbing the GH antiserum with recombinant chicken GH (Amgen, Thousand Oaks, CA, USA; $1 \mathrm{mg} / \mathrm{ml}$ ) for $1 \mathrm{~h}$ prior to section incubation. All tissues collected in paraformaldehyde or Carnoy's fluid were processed together under identical conditions with the same reagents. Digital images were collected using a SPOT digital Microscope Camera (Carsen Group, Markham, Ontario, Canada) mounted on an Olympus B microscope.

\section{Results}

After Carnoy's fixation, intense immunocytochemical staining for GH was seen in the spinal cord, although restricted to the marginal cells of the white matter, to the ventral horn and mantle, to spinal nerves, and to the ventral root nuclei (Fig. 1A, B and C). The surrounding tissue was, however, only faintly stained or unstained. In contrast, strong staining was seen throughout the spinal cord following paraformaldehyde fixation, including the ependymal cells surrounding the spinal canal (Fig. 1D, E and F). In contrast to the tissues fixed in Carnoy's, the tissues fixed in paraformaldehyde had intense GH immunoreactivity in both the ventral and dorsal root ganglia (Fig. 1D, E and F). Similarly, while GH immunoreactivity was abundant and widespread in the notochord, notochordal sheath and in the myotome of paraformaldehyde-fixed tissues (Fig. $2 \mathrm{~B}$ and D), GH immunoreactivity was not detectable in these tissues following Carnoy's fixation (Fig. 2A and C).

A single layer of epithelial cells lining the esophagus (crop) had GH immunoreactivity following Carnoy's fixation (Fig. 3A), although intense GH immunoreactivity was seen in numerous cells in the mucosal epithelium, submucosa and muscular layers of this structure following paraformaldehyde fixation (Fig. 3B). Strong GH staining was, likewise, seen in the bronchus after fixation in paraformaldehyde (Fig. 3D), but only faint staining was seen after fixation in Carnoy's (Fig. 3C). Similar differences in GH staining were also seen in the heart, in which intense staining was present in the myocardium of the atria and in atrial cushions (Fig. 4C and D) and ventricles (Fig. $5 \mathrm{C}$ and $\mathrm{D})$ fixed in paraformaldehyde, but not in the atria 

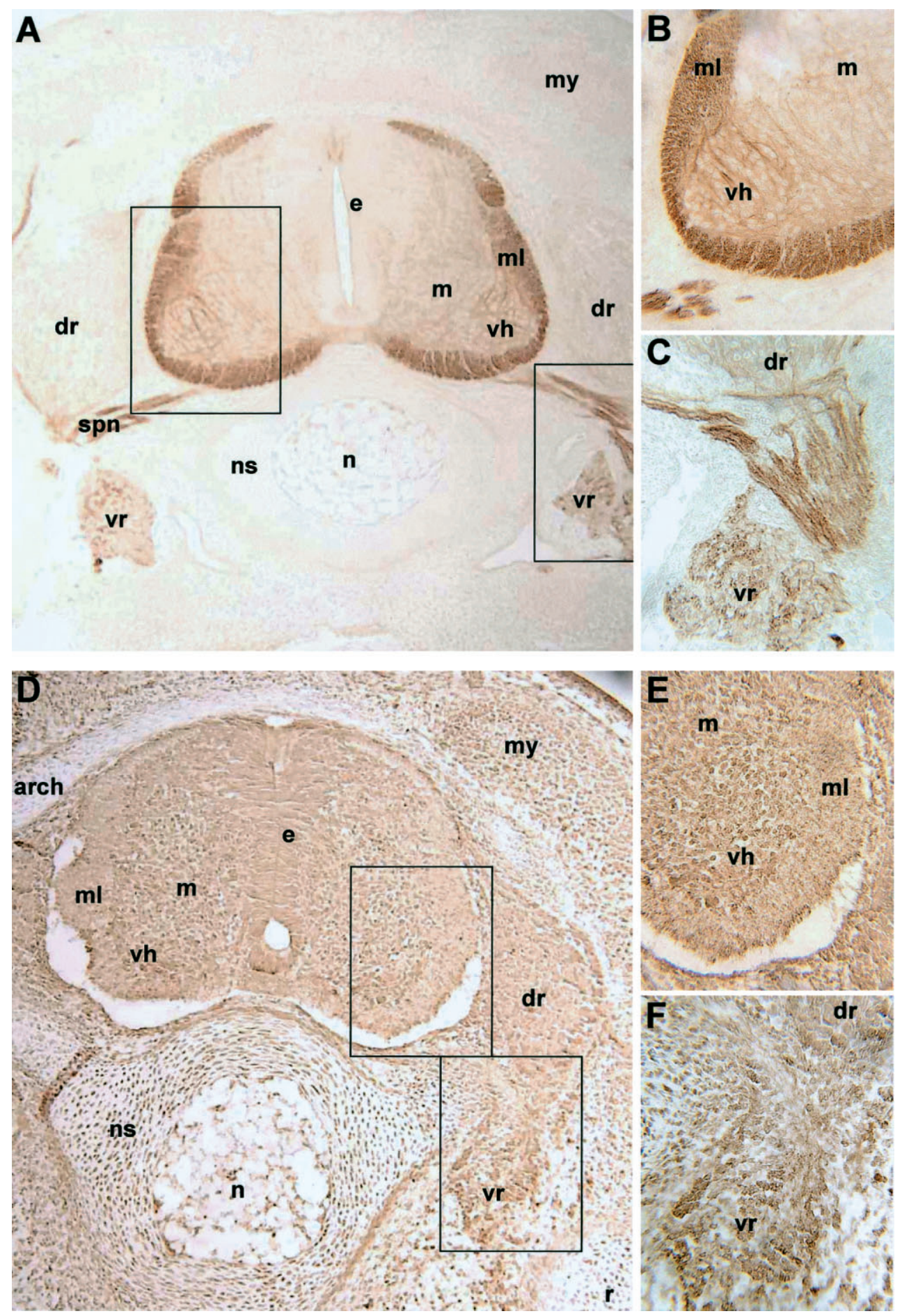

Figure $1 \mathrm{GH}$ immunoreactivity in the spinal cord of embryonic chicks. Following fixation in Carnoy's fluid $(A, B$ and $C)$, intense staining is present in the marginal layer $(\mathrm{ml})$, spinal nerves $(\mathrm{spn})$ and the ventral root nuclei $(\mathrm{vr})$. Light staining is also present in the ventral horn (vh) and the mantle region $(\mathrm{m})$. Magnification: $\mathrm{A} \times 100 ; \mathrm{B} \times 400 ; \mathrm{C} \times 400$. Following fixation in $4 \%(\mathrm{w} / \mathrm{v})$ paraformaldehyde, $\mathrm{GH}$ staining is present throughout the spinal cord, including the ependymal cells (e) surrounding the spinal canal and the dorsal root nuclei $(\mathrm{dr})(\mathrm{D}, \mathrm{E}$ and $\mathrm{F})$. GH immunoreactivity is also present in the ventral root nuclei $(\mathrm{vr})$ and the surrounding myotome (my), vertebral arch (arch), notochord (n), notochordal sheath (ns) and the head of a rib (r). Magnification: $\mathrm{D} \times 100 ; \mathrm{E} \times 400 ; \mathrm{F} \times 400$. 


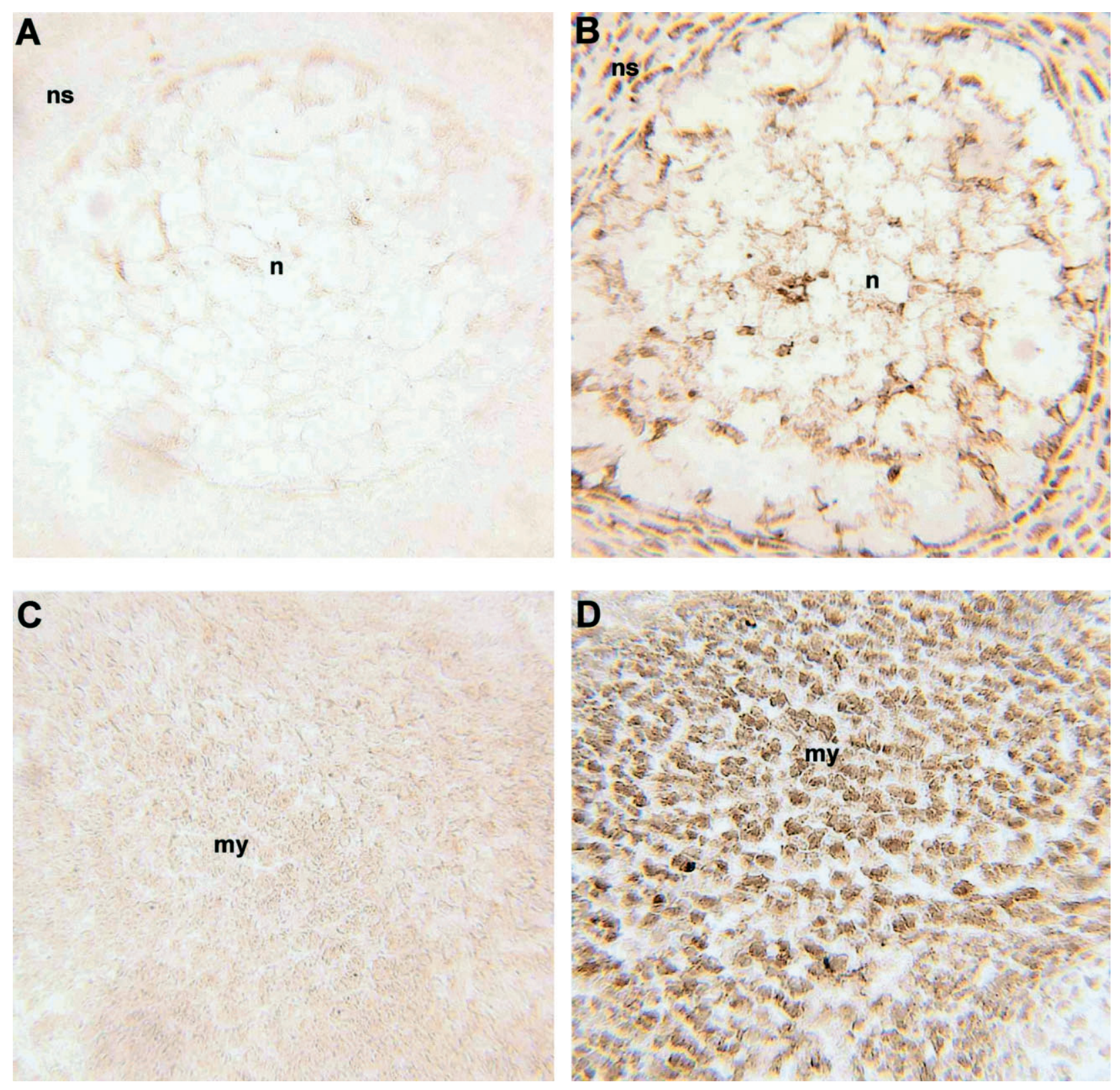

Figure $2 \mathrm{GH}$ immunoreactivity in the notochord (n), notochordal sheath (ns; B) and myotome (my; D) of embryonic chicks following fixation in $4 \%(\mathrm{w} / \mathrm{v})$ paraformaldehyde, in comparison with comparable tissues fixed in Carnoy's fluid (A and C). Magnification: $\times 400$.

(Fig. 4A and B) or ventricles (Fig. 5A and B) fixed in Carnoy's. Strong GH immunoreactivity was also seen in the cells lining the pericardial cavity and in the body wall of embryos fixed in paraformaldehyde (Fig. 4C and D), but not in embryos fixed in Carnoy's (Fig. 4A and B). Although intense staining was present in the myocardial cells of the heart following paraformaldehyde fixation, only faint, diffuse staining was present in blood cells in the atria and ventricles and in the pericardial space (Fig. 4C and D,
Fig. 5C and D). The atrio-pulmonary septum surrounding the ventricles was also only slightly stained following paraformaldehyde fixation (Fig. 5C and D). In marked contrast, there was no staining in myocardial or blood cells of the ventricle following preabsorption of the primary antiserum with excess recombinant GH (Fig. 6).

In the limb bud, strong and discrete $\mathrm{GH}$ staining was localized in the extensor nerve following fixation in Carnoy's (Fig. 7A), whereas GH immunoreactivity was 

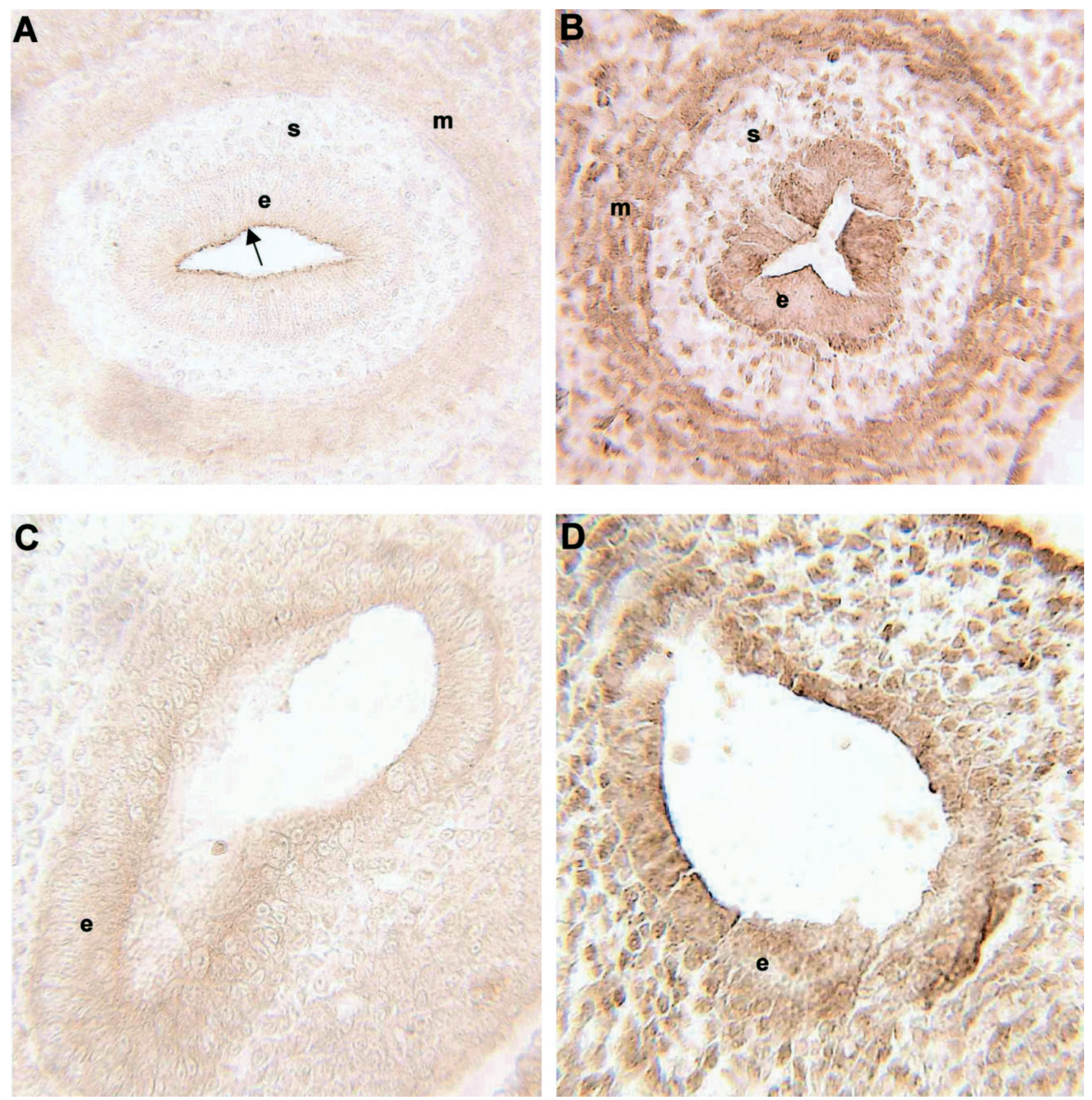

Figure $3 \mathrm{GH}$ immunoreactivity in the esophagus (B) and bronchus (D) of embryonic chicks following fixation in $4 \%(\mathrm{w} / \mathrm{v})$ paraformaldehyde, in comparison with similar tissues fixed in Carnoy's fluid (A and C): Abbreviations: e, epithelium; s, submucosa; $\mathrm{m}$, esophageal muscularis. Magnification: $\times 400$. Only a single layer of esophageal epithelial cells (arrowed) were GH immunoreactive following Carnoy's fixation, whereas GH immunoreactivity was widespread following paraformaldehyde fixation.

widespread in the limb bud fixed in paraformaldehyde. Following paraformaldehyde fixation, GH immunoreactivity was particularly abundant in chondrocytes of the humerus (Fig. 7F) (as in chondrocytes in the ribs, Fig. 1D) and in a layer of outer epidermal cells (Fig. 7E), which were only faintly stained or unstained after Carnoy's fixation (Fig. 7B and C). Intense GH immunoreactivity was also present in the dorsal and ventral muscle mass of the wing bud following paraformaldehyde fixation (Fig. 7D), but not after Carnoy's (Fig. 7A).

In all tissues fixed in Carnoy's or paraformaldehyde, the GH staining was specific and completely lost following preabsorption of the primary antibody with excess recombinant GH (data not shown). The data shown are also 

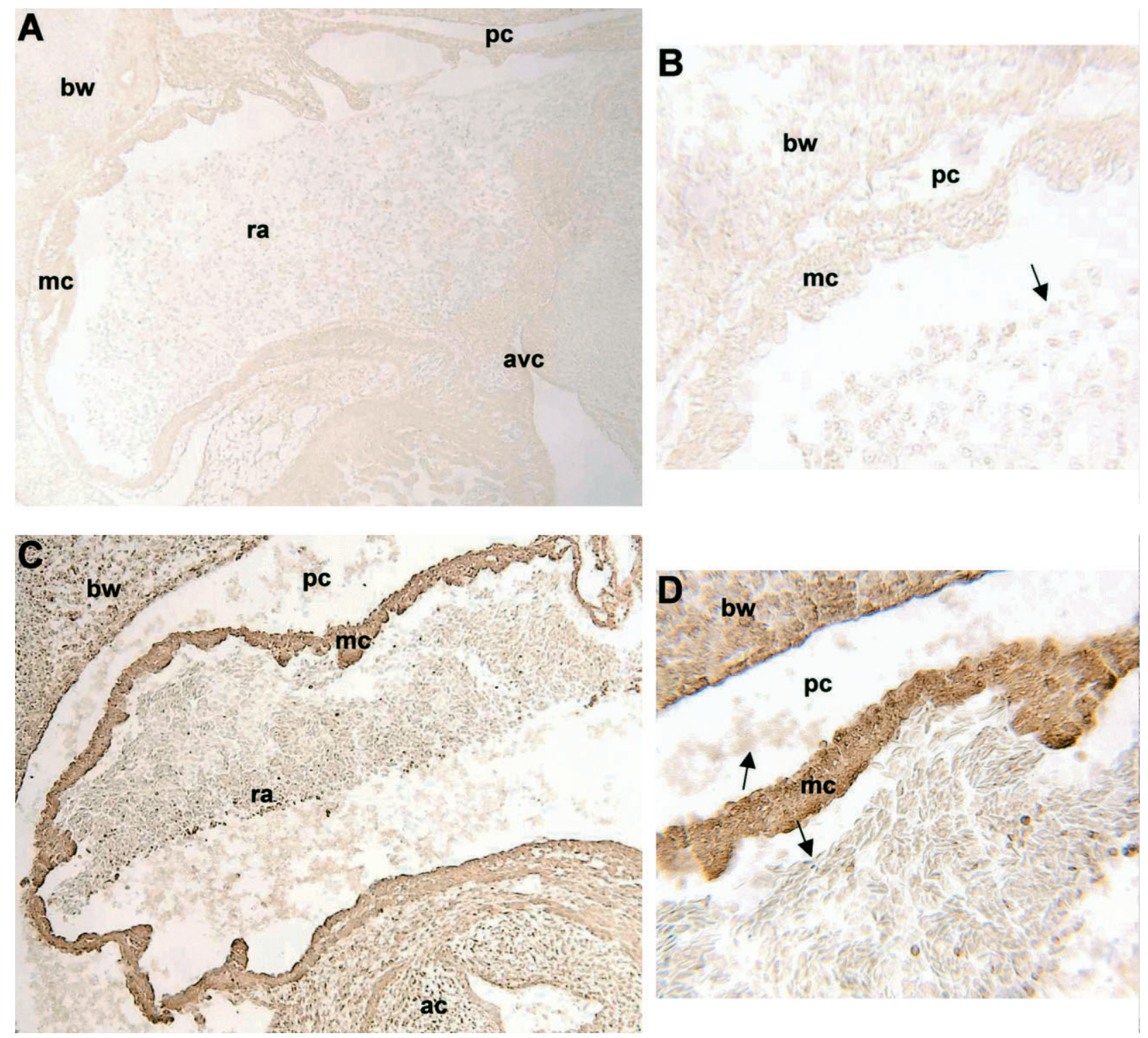

Figure $4 \mathrm{GH}$ immunoreactivity in the atria of embryonic chicks following fixation in $4 \%(\mathrm{w} / \mathrm{v})$ paraformaldehyde (C and D), in comparison with atria fixed in Carnoy's fluid (A and B). Intense GH immunoreactivity is present throughout the myocardium (mc) of the right atria (ra), atrial cushion (ac) and the body wall (bw) following fixation in paraformaldehyde (C and D). Only faint, diffuse staining to blood cells (arrowed) is seen in the atrium and pericardial cavity. Magnification: A and C $\times 100$; B and D $\times 400$. Abbreviations: avc, atrio-ventricular canal; pc, pericardial cavity.

representative of sections taken from at least 20 embryos fixed in Carnoy's and at least 20 embryos fixed in paraformaldehyde.

\section{Discussion}

These results clearly showed the presence of GH-like proteins in peripheral tissues of early chick embryos, but demonstrate tissue-specific differences in staining following paraformaldehyde or Carnoy's fixation.
The distribution of $\mathrm{GH}$ immunoreactivity in the peripheral tissues of paraformaldehyde-fixed ED 7 chicks was widespread, but particularly striking in the spinal cord, dorsal and ventral root ganglia, notochord, myotome, epidermis, heart and the humerus. These findings extend preliminary observations by Harvey et al. (2000) using paraformaldehyde-fixed tissues from ED 6 and ED 7 embryos. The cellular localization of GH staining in the neural tube, dorsal and ventral root ganglia, notochord, heart and limb bud was, however, much clearer in this 

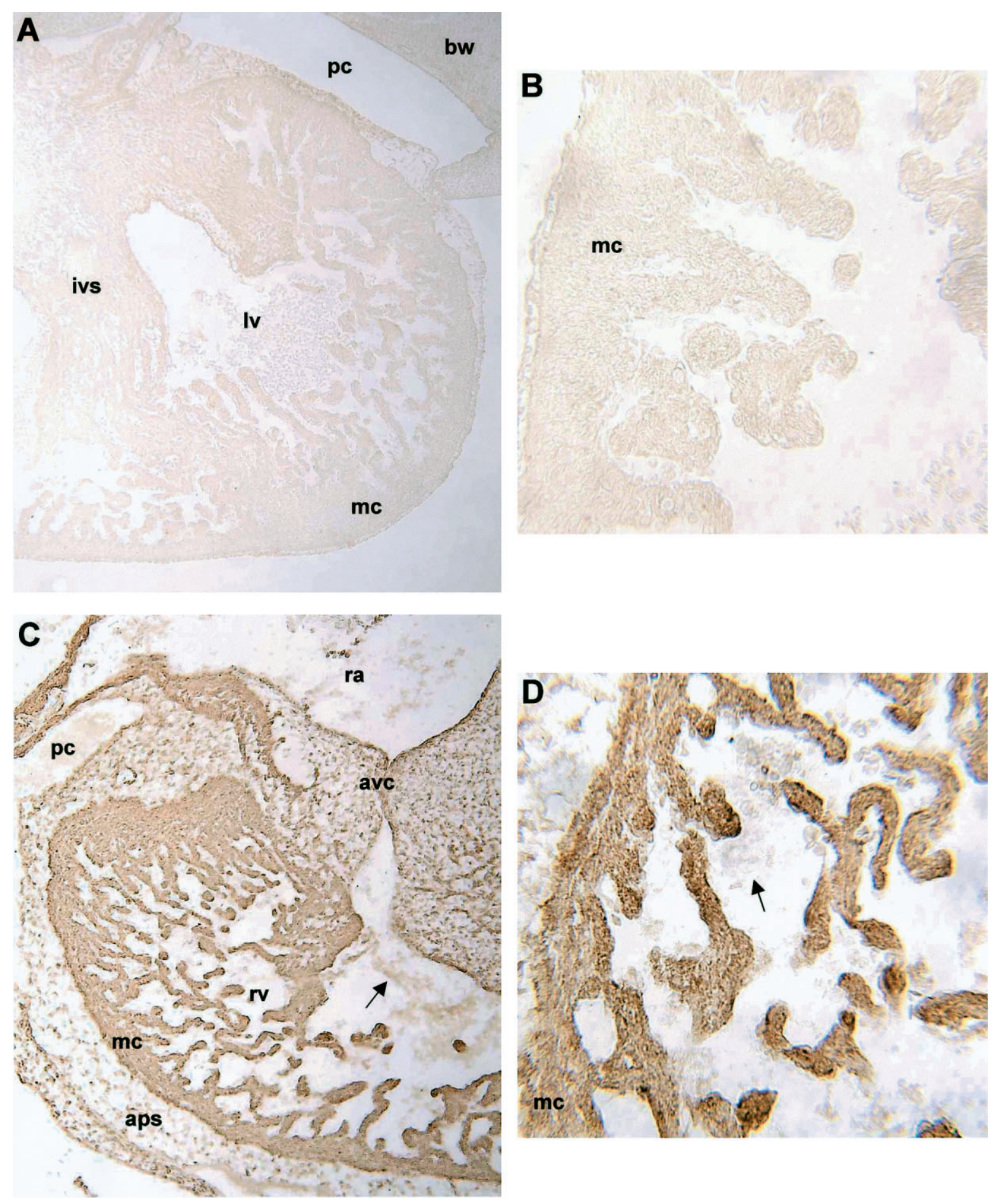

Figure $5 \mathrm{GH}$ immunoreactivity in the ventricles of chick embryos following fixation in $4 \%(\mathrm{w} / \mathrm{v})$ paraformaldehyde $(\mathrm{C}$ and $\mathrm{D})$, in comparison with ventricles fixed in Carnoy's fluid (A and B). Intense GH immunoreactivity is present throughout the ventricular myocardium $(\mathrm{mc})$ of tissues fixed in paraformaldehyde, whereas only faint $\mathrm{GH}$ staining is present in the aortico-pulmonary septum (aps) or to blood cells (arrowed) in the ventricular lumen. In contrast, GH immunoreactivity is not seen in ventricular tissue fixed in Carnoy's (A and B). Abbreviations: ra, right atrium; avc, atrio-ventricular canal; ivs, intraventricular septum; bw, body wall; pc, pericardial cavity; lv, left ventricle; rv, right ventricle. Magnification: A and C $\times 100$; B and D $\times 400$. 

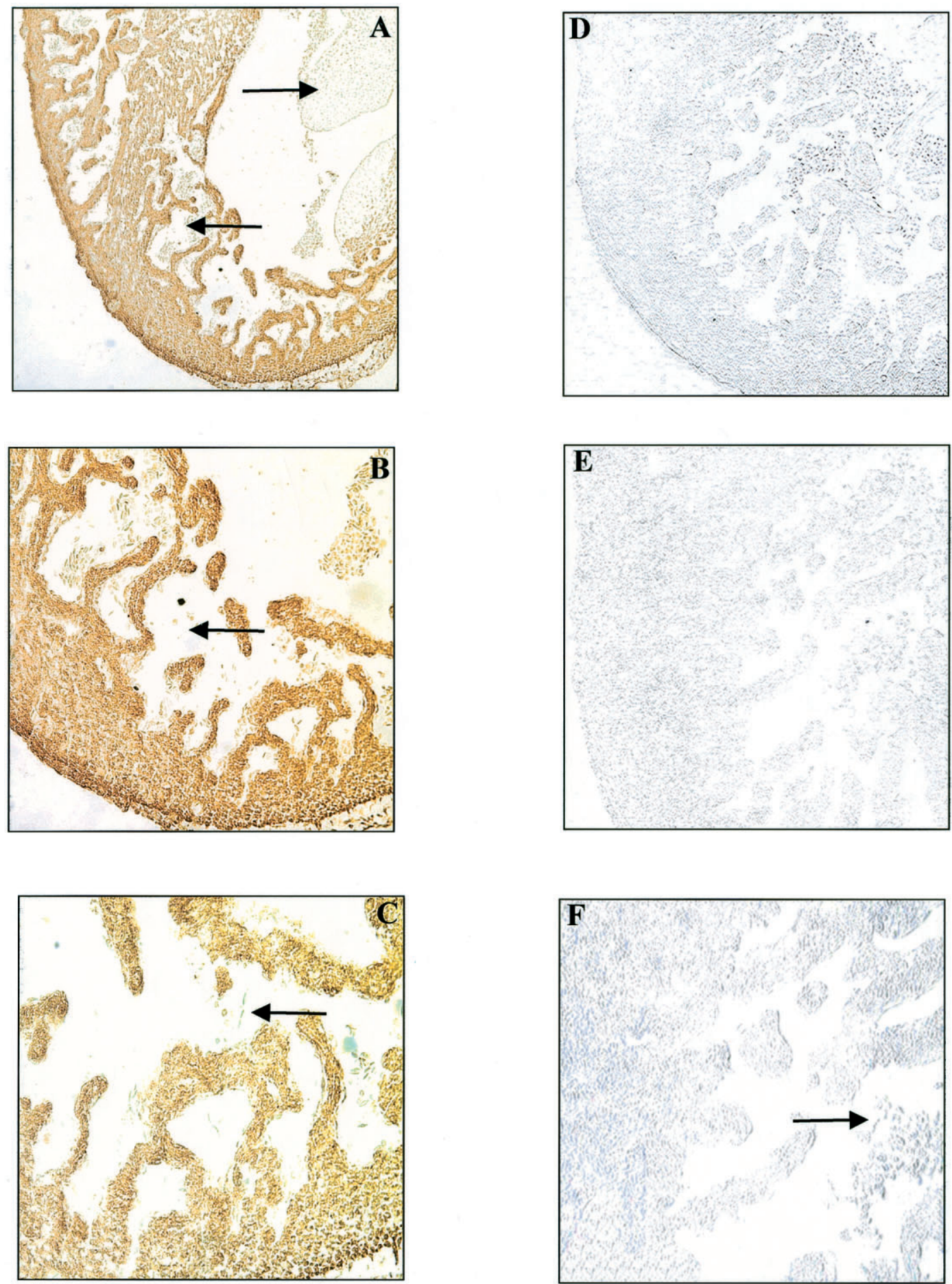

Figure $6 \mathrm{GH}$ immunoreactivity in the ventricles of chick embryos following fixation in $4 \%(\mathrm{w} / \mathrm{v})$ paraformaldehyde before $(A, B$ and $C)$ or after $(D, E$ and $F)$ the primary antiserum had been preabsorbed with excess recombinant chicken $\mathrm{GH}(1 \mathrm{mg} / \mathrm{ml}$ for $1 \mathrm{~h})$. The arrows indicate faint diffuse staining in blood cells. Magnification: A and D $\times 100 ; \mathrm{B}$ and $\mathrm{E} \times 200 ; \mathrm{C}$ and $\mathrm{F} \times 400$. 

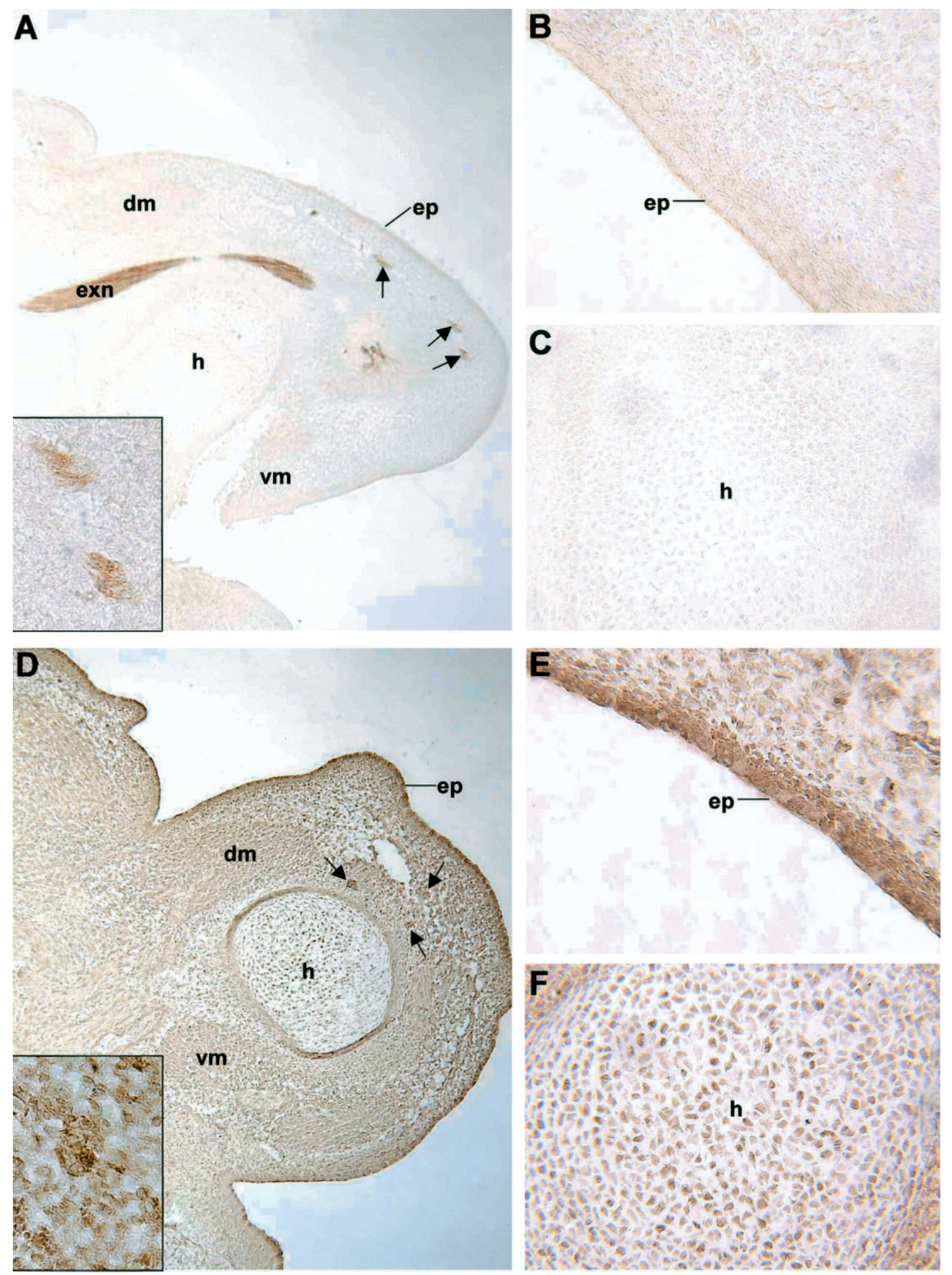

Figure $7 \mathrm{GH}$ immunoreactivity in the chick embryo wing bud following fixation in Carnoy's fluid (A, B and C) or $4 \%$ $(\mathrm{w} / \mathrm{v})$ paraformaldehyde $(\mathrm{D}, \mathrm{E}$ and $\mathrm{F})$. Intense $\mathrm{GH}$ staining is present in the extensor nerve (exn, and arrows) following fixation in Carnoy's (A and B), although cells in the dorsal $(\mathrm{dm})$ and ventral $(\mathrm{vm})$ muscle masses, the epidermis (ep) and the humerus (h) were unstained. In contrast, strong $\mathrm{GH}$ immunoreactivity is seen throughout the wing bud following paraformaldehyde fixation, but is particularly striking in the extensor nerve (arrows), muscle masses, epidermis and humerus (D, E and F). Magnification: $A$ and $D \times 100 ; B, C, E$ and $F \times 400$. The insets show tracts of extensor nerve at $\times 1000$ magnification. 
study and is presented at high magnification for the first time. The staining for $\mathrm{GH}$ in these tissues is clearly cellular and within the cytoplasm, whereas it could not be clearly differentiated from background staining in the earlier study (Harvey et al. 2000). The presence of GH staining in the esophagus (crop), lung (bronchus), myotome and the anterior extensor nerve following paraformaldehyde staining are novel observations.

A widespread distribution of $\mathrm{GH}$ immunoreactivity might be expected, since the headless bodies of ED 6 and ED 8 embryos readily express the GH gene (Harvey et al. 2000). A widespread cellular distribution of $\mathrm{GH}$ immunoreactivity might also be expected in view of the finding, in mammals, of GH mRNA and immunoassayable GH in extracts of most peripheral tissues (e.g. Kyle et al. 1981, Costa et al. 1993, Wu et al. 1996, Recher et al. 2001), particularly in perinatal animals (Costa et al. 1993, Recher et al. 2001). A widespread distribution of $\mathrm{GH}$ immunoreactivity might also be expected, since GH may act as an autocrine or paracrine growth factor during embryonic development (Harvey \& Hull 1997), and GH receptors (Harvey et al. 2000) and a GH-responsive gene (Harvey et al. 2001a) are ubiquitous in embryonic tissues. Extrapituitary GH is thus likely to be involved in normal embryogenesis or fetal development. Extrapituitary GH is, however, likely to be only one of many growth factors that jointly regulate ontogenic development (Adamson 1993, Waters et al. 1999) and GH is unlikely to be critically required, since normal or near-normal development occurs in dwarf chickens and mammals with GH receptor dysfunction (Hull \& Harvey 1999). Other growth factors are thus likely to compensate for $\mathrm{GH}$ under conditions of $\mathrm{GH}$ or GH receptor dysfunction. Under normal conditions, extrapituitary GH may act as an autocrine/paracrine factor to stimulate growth by acting as a cell survival factor. Indeed, a recent study has shown that GH reduces apoptosis in bovine embryos during early embryogenesis (Kolle et al. 2002).

The distribution of $\mathrm{GH}$ immunoreactivity in ED 7 tissues fixed in Carnoy's was noticeably different from that observed following paraformaldehyde fixation. After Carnoy's, the immunohistochemical staining of GH was more discrete (mainly restricted to marginal and mantle layers of the spinal cord, the ventral root ganglia, to spinal nerves and to the anterior extensor nerve). These results are similar to those published by Murphy \& Harvey (2001), in which GH staining was also observed in the trigeminal nerve and vagal nerve following Carnoy's fixation. This suggests that Carnoy's fixative preferentially detects GH immunoreactivity in neural tissues. The discrete presence of $\mathrm{GH}$ in the extensor nerve is a novel finding of this study, as is the absence of GH staining in chondrocytes and cardiac cells fixed in Carnoy's fluid. Indeed, apart from the neural derivatives, GH immunoreactivity is barely detectable in the peripheral tissues of embryos fixed in Carnoy's. It is therefore of interest that the GH staining in the heads of ED 7 chicks fixed in Carnoy's (Murphy \& Harvey 2001) was also much less than in heads fixed in paraformaldehyde (Harvey et al. 2001b). This is particularly evident for Rathke's pouch (a non-neural pharyngeal derivative that differentiates into the pituitary gland), which is almost devoid of $\mathrm{GH}$ immunoreactivity following Carnoy's fixation (Murphy \& Harvey 2001) but abundantly stained for GH immunoreactivity following paraformaldehyde fixation (Harvey et al. 2001b). The controversy in the literature (Porter 1997) on the ontogeny of pituitary somatotrophs (ED 4.5, Thommes et al. 1987 (Bouin's fixation); ED 10, Malamed et al. 1993 (Zenker's fixative); ED 12, Józsa et al. 1979, Allaerts et al. 1999 (Zamboni's fluid); ED 12, Porter et al. 1995 (B-5; formalin-mercuric chloride)), might therefore partly reflect differences in the fixatives used. Qualitative differences in the distribution of $\mathrm{GH}$ staining in other tissues of embryonic chicks may similarly reflect differences in tissue fixation. For instance, while Harvey et al. (2001b) observed widespread staining for GH in neural retinas fixed in paraformaldehyde, Takeuchi et al. (2001) found $\mathrm{GH}$ immunoreactivity only in pigmented retinal epithelial cells following fixation in Bouin's (a picric acid-based fixative).

Paraformaldehyde is a cross-linking fixative and is particularly useful for fixing smaller proteins and peptides (Polak \& Van Noorden 1997). Carnoy's, in contrast, is a precipitant fixative and more useful for the fixation of large proteins. Carnoy's fluid is a better fixative than paraformaldehyde in preserving tissue architecture and in facilitating tissue sectioning (Polak \& Van Noorden 1997), but it reduces specific staining for GH immunoreactivity. Carnoy's fixative has similarly been found to reduce antigen staining in other immunocytochemical studies, in comparison with formalin or paraformaldehyde (e.g. Cammer et al. 1985, Schutte et al. 1987, Bos et al. 2000). It is therefore possible that Carnoy's and paraformaldehyde fixatives may differentially fix the different GH moieties present in neural and non-neural tissues. It is now well established that pituitary GH comprises a family of size and charge variants that may result from differential gene transcription or post-translational modifications (Arámburo et al. 2000, 2001a,b; Martínez-Coria et al. 2002). This may include oligomerization (into dimers, trimers, quadramers and pentamers) and proteolytic cleavage (into fragments of $15 \mathrm{kDa}$ and $7 \mathrm{kDa}$ ) of the monomer (26 kDa) moiety (Arámburo et al. 2001b). Small GH moieties of $14 \mathrm{kDa}$ to $17 \mathrm{kDa}$ have also been identified in pituitary extracts and, interestingly, these are preferentially produced in embryonic chicks (Arámburo et al. 2000). GH size heterogeneity has also been identified in the testes of embryonic and adult chickens (Luna et al. 2000, M Luna, L Huerta, L Berúmen, H Martínez-Coria, S Harvey \& C Arámburo, unpublished observations), in which the submonomer variants are the most abundant moieties, particularly in embryonic tissues. Submonomer 
$\mathrm{GH}$ variants are also present in the eyes of chick embryos, but not in the eyes of neonatal chicks (Takeuchi et al. 2001). Submonomer GH moieties, therefore, appear to be more abundant in peripheral extrapituitary tissues than in the pituitary and more abundant in embryos than in neonatal or adult chickens. It is, therefore, possible that these smaller moieties are not fixed by Carnoy's fluid, underestimating the $\mathrm{GH}$ immunoreactivity that is detected by the cross-linking of small and large GH proteins during paraformaldehyde fixation. Fixation with Carnoy's fluid does, however, appear to selectively label $\mathrm{GH}$ in neural derivatives, and it may be more useful than paraformaldehyde for immunohistochemical studies on neural GH. This selectivity may, interestingly, reflect the fact that no submonomer $\mathrm{GH}$ moieties are present in Western blots of hypothalamic and extrahypothalamic brain tissues (Render et al. 1995a), whereas submonomer GH moieties are abundantly present in the other nonneural tissues (Render et al. 1995a, Luna et al. 2000, Harvey et al. 2002, M Luna, L Huerta, L Berúmen, H Martínez-Coria, S Harvey \& C Arámburo, unpublished observations).

In summary, qualitative and quantitative differences in tissue GH immunoreactivity are evident in immunohistochemical studies employing paraformaldehyde and Carnoy's fixatives. The presence of GH immunoreactivity in the embryonic chick is underestimated by fixation in Carnoy's fluid, and caution should be used in interpreting immunohistochemical data obtained with this fixative.

\section{Acknowledgements}

This work was supported by a grant from the Natural Sciences and Engineering Research Council (NSERC) of Canada. A E M is in receipt of a studentship from NSERC, and M-L Baudet is in receipt of a studentship from the Alberta Heritage Foundation for Medical Research.

\section{References}

Adamson ED 1993 Activities of growth factors in preimplantation embryos. Journal of Cellular Biochemistry 53 280-287.

Allaerts W, Boonstra-Blom AG, Peeters K, Janse EM, Berghman LR \& Jeurissen SH 1999 Prenatal development of hematopoietic and hormone-producing cells in the chicken adenohypophysis. General and Comparative Endocrinology 114 213-224.

Allen JT, Bloor CA, Kedia RK, Knight RA \& Spiteri MA 2000 Expression of growth hormone-releasing factor, growth hormone, insulin-like growth factor-1 and its binding proteins in human lung. Neuropeptides 34 98-107.

Arámburo C, Luna M, Carranza M, Reyes M, Martínez-Coria H \& Scanes CG 2000 Growth hormone size variants: changes in the pituitary during development of the chicken. Proceedings of the Society for Experimental Biology and Medicine 223 67-74.

Arámburo C, Carranza M, Martínez-Coria H, Reyes M, Berúmen L, López-Rosales LJ, Pascacio H, Huerta L \& Luna M 2001a
Molecular and functional heterogeneity of growth hormone. In Avian Endocrinology, pp 273-286. Eds A Dawson \& CM Chaturvedi. New Delhi: Narosa Publishing House.

Arámburo C, Carranza M, Reyes M, Luna M, Martínez-Coria H, Berúmen L \& Scanes CG $2001 b$ Characterization of a bioactive $15 \mathrm{kDa}$ fragment produced by proteolytic cleavage of chicken growth hormone. Endocrine 15 231-240.

Bos PK, van Osch GJ, van der Kwast T, Verwoerd-Verhoef HL \& Verhaar JA 2000 Fixation-dependent immunolocalization shift and immunoreactivity of intracellular growth factors in cartilage. Histochemical Journal 32 391-396.

Cammer W, Sacchi R \& Sapirstein V 1985 Immunocytochemical localization of carbonic anhydrase in the spinal cords of normal and mutant (shiverer) adult mice with comparisons among fixation methods. Journal of Histochemistry and Cytochemistry 33 45-54.

Chiu KY, Loke SL \& Ho FC 1994 Immunohistochemical demonstration of c-erbB-2 oncoprotein in gastric adrenocarcinoma: comparison of cryostat and paraffin wax sections and effect of fixation. Journal of Clinical Pathology 47 117-121.

Costa A, Zoppetti G, Benedetto C, Bertino E, Marozio L, Fabris C, Arisio R, Giraudi GF, Testori O, Ariano M, Maula V \& Bertini E 1993 Immunolike growth hormone substance in tissues from human embryos/fetuses and adults. Journal of Endocrinological Investigation 16 625-633.

Giaccone G, Canciani B, Puoti G, Rossi G, Goffredo D, Iussich S, Fociani P, Tagliavini T \& Bugiani O 2000 Creutzfeldt-Jakob disease: Carnoy's fixative improves the immunohisto-chemistry of the proteinase K-resistant prior protein. Brain Pathology 10 31-37.

Harvey S \& Hull KL 1997 Growth hormone: a paracrine growth factor? Endocrine 7 267-279.

Harvey S, Johnson CDM \& Sanders EJ 2000 Extra-pituitary growth hormone in peripheral tissues of early chick embryos. Journal of Endocrinology 166 489-502.

Harvey S, Lavelin I \& Pines M 2001a Growth hormone (GH) action in early embryogenesis: expression of a $\mathrm{GH}$-response gene in sites of GH production and action. Anatomy and Embryology 204 503-510.

Harvey S, Johnson CDM \& Sanders EJ $2001 b$ Growth hormone in neural tissues of the chick embryo. Journal of Endocrinology 169 487-498.

Harvey S, Murphy AE, Hull KL, Luna M \& Arámburo C 2002 Testicular growth hormone $(\mathrm{GH})$ and $\mathrm{GH}$ mRNA. Growth Hormone and IGF-1 Research 12262.

Hemmer MJ, Courtney LA \& Benson WH 1998 Comparison of three histological fixatives on the immunoreactivity of mammalian P-glycoprotein antibodies in the sheepshead minnow, Cyprinodon variegates. Journal of Experimental Zoology 291 251-259.

Hsu SM, Raine L \& Fanger H 1981 Use of avidin-biotin-peroxidase complex $(\mathrm{ABC})$ in immuno-peroxidase techniques: a comparison between $\mathrm{ABC}$ and unlabeled antibody (PAP) procedures. Journal of Histochemistry and Cytochemistry 29 577-590.

Hull KL \& Harvey S 1999 Growth hormone resistance: clinical states and animal models. Journal of Endocrinology 163 165-172.

Józsa R, Scanes CG, Vigh S \& Mess B 1979 Functional differentiation of the embryonic chick pituitary gland studies by immunohistological approach. General and Comparative Endocrinology 39 159-163.

Kao T-L, Supowit SC, Thompson EA \& Meyer WJ III 1992 Immunoreactive growth hormone production by human lymphocyte cell lines. Cellular and Molecular Neurobiology 12 483-498.

Kolle S, Stojkovic M, Boie G, Wolf E \& Sinowatz F 2002 Growth hormone inhibits apoptosis in in vitro produced bovine embryos. Molecular and Reproductive Development 61 180-186.

Kyle CV, Evans MC \& Odell WD 1981 Growth hormone-like material in normal human tissues. Journal of Clinical Endocrinology and Metabolism 53 1138-1144. 
Lechan RM, Nestler JL \& Molitch ME 1981 Immunohistochemical identification of a novel substance with human growth hormonelike immunoreactivity in rat brain. Endocrinology 109 1948-1962.

Luna M, Martínez-Coria H, Carranza M, Huerta L, Harvey S \& Arámburo C 2000 Characterization of growth hormone molecular variants and gene expression in extra-pituitary tissues in the chicken. Proceedings of the European Society for Comparative Endocrinology, Portugal, p 63.

Maggiano N, Piantelli M, Ricci R, Larocca LM, Capelli A \& Ranelletti FO 1994 Detection of growth hormone-producing cells in human thymus by immunohistochemistry and non-radioactive in situ hybridization. Journal of Histochemistry and Cytochemistry 42 1349-1354.

Malamed S, Gibney JA, Cain LD, Perez FM \& Scanes CG 1993 Immuno-cytochemical studies of chicken somatotrophs and somatotroph granules before and after hatching. Cell and Tissue Research 272 369-374.

Martínez-Coria H, López-Rosales LJ, Carranza M, Berúmen L, Luna M \& Arámburo C 2002 Differential secretion of chicken growth hormone variants after growth hormone-releasing hormone stimulation in vitro. Endocrine 17 91-102.

Mol JA, Henzen-Logmans SC, Hageman WP, Misdorp W, Blankenstein MA \& Rujnberk A 1995a Expression of the gene encoding growth hormone in the human mammary gland. Journal of Clinical Endocrinology and Metabolism 80 3094-3096.

Mol JA, van Garderen E, Selman PJ, Wolfswinkel J, Rijnberk A \& Rutteman GR 1995b Growth hormone mRNA in mammary gland tumors of dogs and cats. Journal of Clinical Investigation $\mathbf{9 5}$ 2028-2034.

Murphy AE \& Harvey S 2001 Extrapituitary $\beta$ TSH and GH in early chick embryos. Molecular and Cellular Endocrinology 185 161-171.

Palmetshofer A, Zechner D, Luger TA \& Barta A 1995 Splicing variants of the human growth hormone mRNA: detection in pituitary, mononuclear cells and dermal fibroblasts. Molecular and Cellular Endocrinology 113 225-234.

Polak JM \& Van Noorden S 1997 Introduction to Immunocytochemistry, edn 2. New York: Springer-Verlag.

Porter TE 1997 Regulation of somatotrophs differentiation during chicken embryonic development: a review. In Perspectives in Avian Endocrinology, pp 47-56. Eds S Harvey \& RJ Etches. Bristol: Society for Endocrinology.

Porter TE, Couger GS, Dean CE \& Hargis BM 1995 Ontogeny of growth hormone $(\mathrm{GH})$-secreting cells during chick embryonic development: initial somatotrophs are responsive to GH-releasing hormone. Endocrinology 136 1850-1856.

Ramesh R, Kuenzel WJ, Buntin JD \& Proudman JA 2000 Identification of growth hormone and prolactin containing neurons within the avian brain. Cell and Tissue Research 299 371-383.
Recher S, Raccurt M, Lambert A, Lobie PE, Mertani HC \& Morel G 2001 Prenatal and adult growth hormone gene expression in rat lymphoid organs. Journal of Histochemistry and Cytochemistry 49 347-354.

Render C, Hull KL \& Harvey S 1995a Neural expression of the pituitary GH gene. Journal of Endocrinology 147 413-422.

Render C, Hull KL \& Harvey S 19956 Expression of the growth hormone gene in immune tissues. Endocrine 3 729-735.

Schutte B, Reynders MM, Bosman FT \& Blijham GH 1987 Effect of tissue fixation on anti-bromodeoxyuridine immunohistochemistry. Journal of Histochemistry and Cytochemistry 35 1343-1345.

Schwarzler P, Untergasser G, Hermann M, Dirnhofer S, Abendstein B, Madersbacher S \& Berger P 1997 Selective growth hormone/placental lactogen gene transcription and hormone production in pre- and postmenopausal human ovaries. Journal of Clinical Endocrinology and Metabolism 82 3337-3341.

Slominski A, Malarkey WB, Wortsman J, Asa SL \& Carlson A 2000 Human skin expresses growth hormone but not the prolactin gene. Journal of Laboratory and Clinical Medicine 136 476-481.

Takeuchi S, Haneda M, Teshigawara K \& Takahashi S 2001 Identification of a novel GH isoform: a possible link between $\mathrm{GH}$ and melanocortin systems in the developing chicken eye. Endocrinology 142 5158-5166.

Thommes RC, Umporowicz DM, Leung FCD \& Woods JE 1987 Ontogenesis of immunocytochemically demonstrable somatotrophs in the adenohypophyseal pars distalis of the developing chick embryo. General and Comparative Endocrinology 67 390-398.

Tresguerres JA, Ariznavarreta C, Granados B, Costoy JA, PérezRomero A, Salamé F \& Hermanussen M 1999 Salivary gland is capable of GH synthesis under GHRH stimulation. Journal of Endocrinology 160 217-222.

Vince DG, Tbakhi A, Gaddipati A, Cothren RM, Cornhill JF \& Tubbs RR 1997 Quantitative comparison of immunohistochemical staining intensity in tissues fixed in formalin and Histochoice. Anatomy and Cell Pathology 15 119-129.

Waters MJ, Sheng CA, Belachen SN, Tam SP, Li H, Shen B \& Lobie PE 1999 Growth hormone as a cytokine. Clinical and Experimental Pharmacology and Physiology 26 760-764.

Wu H, Devi R \& Malarkey WB 1996 Localization of growth hormone messenger ribonucleic acid in the human immune system - a clinical research study. Journal of Clinical Endocrinology and Metabolism 81 1278-1282.

Zhang CZ, Li H, Young WG, Bartold PM, Chen C \& Waters MJ 1997 Evidence for a local action of growth hormone in embryonic tooth development in the rat. Growth Factors 14 131-143.

Received in final form 15 January 2003

Accepted 16 January 2003 